\title{
Management Of Macrolide Antibiotics (Erythromycin, Clarithromycin And Azithromycin) In The Environment: A Case Study Of Environmental Pollution In Lithuania
}

Inga Baranauskaitė-Fedorova ( $\boldsymbol{Q}$ inga.baranauskaite22@gmail.com )

KTU: Kauno Technologijos Universitetas https://orcid.org/0000-0002-2503-8086

Reda Beigaite

Kaunas University of Technology: Kauno Technologijos Universitetas

Jolanta Dvarioniene

Kaunas University of Technology: Kauno Technologijos Universitetas

\section{Research Article}

Keywords: erythromycin, clarithromycin, azithromycin, substance flow analysis, environmental risk assessment, pharmaceutical substances management

Posted Date: March 2nd, 2022

DOI: https://doi.org/10.21203/rs.3.rs-1312184/v1

License: () (i) This work is licensed under a Creative Commons Attribution 4.0 International License. Read Full License 


\section{Abstract}

Of all the antibiotics used today for human treatment in the world, macrolide antibiotics - erythromycin, clarithromycin and azithromycin - stand out the most for misuse, and were included as high-risk substances in the monitoring Watch List of Regulation 2018/840/EU. The aim of the present research was to investigate the level of target human pharmaceuticals prevalence in the environment by the substance flow analysis (SFA) approach and to determine the antibiotics potential risks for the environment. The target for the environmental investigations were the Baltic Sea region, the country of Lithuania. For SFA, 2015-2018 input data were used and such key processes as consumption of antibiotics, disposal and distribution of pharmaceuticals in the environment were analysed. The analysis revealed that the largest part of pharmaceutical contaminants $(72 \%)$ enters wastewater treatment plants. The risk quotient approach was based on the determination of predicted environmental concentrations (PECs), measured environmental concentrations (MECs), and their ratio to the predicted no-effect environmental concentrations (PNECs). The analysis revealed that clarithromycin and azithromycin cause potential risk for the aquatic environment (PEC/PNEC > 1). The concentration of clarithromycin in the effluents of Klaipeda WWTP showed an exceptionally high risk to the natural environment. Recommendations on how to reduce the release of pharmaceutical residues into the environment were proposed in the framework of the environmental management system.

\section{Introduction}

Macrolides are ranked by the World Health Organization as some of the most important antibiotics in the world for human medicine. Antibiotics are most commonly known as medicines for the treatment of infectious diseases in humans and animals, or as livestock growth promoters used in agriculture and aquaculture (Hu et al., 2018). Excessive and increasing use of antibiotics and abuse of these pharmaceuticals trigger public concern (Gelband et al., 2015). The fact that their occurrence may accelerate the spread of antibiotic resistance of the natural environment is of greatest concern (BengtssonPalme et al., 2018), and thus affect the humans.

Even up to $90 \%$ of pharmaceutical substances enter the environment in their original form (COM 2020). Antibiotics, however, are excreted as metabolites or parent compounds, which, in case of incomplete metabolism, are not fully broken down in the intestine and after passing through an artificial environment they enter the aquatic environment and ecosystems (Chen et al., 2020). Their residues enter the aquatic and terrestrial environment in a variety of ways, usually from municipal wastewater released from urban treatment plants or due to improper disposal of unused medicines (Ben et al., 2019; Baranauskaite et al., 2014a, 2014b).

In Lithuania, consumption of pharmaceutical substances is similar to the average of European countries. Particularly high consumption of antibiotics and their incorrect disposal are observed in the country. Based on the data collected by ESAC-Net, consumption of antibiotics in 2015-2018 was stable enough, but it increased by $11.4 \%$ in 2018 (see Figure 1). Consumption of clarithromycin stood out from the consumption of other antibiotics - consumption of this antibiotic increased by $18 \%$ in four years. 
According to the data collected by ESAC-Net, the total consumption of antibiotics in Lithuania in 2018, as assessed on the basis of DDD / 1,000 residents per day factor, is around 17.5. Looking at the period 20152018 in general, it can be seen that the highest consumption of antibiotics in Lithuania was in $2018-17.5$ DDD / 1,000 residents per day, and the lowest was in 2016 - 15.6 DDD / 1,000 residents per day. Based on statistics, macrolides, as a group of test substances, are ranked second according to the consumption of antibiotics in Lithuania. Considering the test substances alone, consumption of clarithromycin is the highest. After the average of the test substances was obtained, the following consumption of antibiotics has been observed in Lithuania: $76 \%$ of clarithromycin, $23 \%$ of azithromycin and $1 \%$ of erythromycin (see Figure 2).

Lithuania is one of the Baltic States that contribute to the pollution of the Baltic Sea. Here, an average of 1,800 tons of pharmaceutical products per year enter the sea (HELCOM 2018). This fact strongly motivated to start an investigation on the sources, discharges and related risks for the environment of the pharmaceutical substances - erythromycin, clarithromycin and azithromycin consumed in the Baltic Sea region of Lithuania. The main objective of this research was to perform a substance flow analysis at the level of the whole country and evaluate the environmental impact risk assessment of the investigated substances to show the impact on the Baltic Sea environment, and to provide recommendations on how to accurately reduce pollution and leakage of these substances.

\section{Material And Methods}

\subsection{Macrolide antibiotic substance flow analysis}

The Mathematical Material Flow Analysis (MMFA) method is used to perform material flow analysis. This method is designed to describe and simulate material flows in mathematical models in order to understand the system and investigate the possible causes of material flows, as well as to design sustainable, environmentally friendly measures for flow management (Bader et al., 2017, Baranauskaite et al., 2014b).

The annual consumption of azithromycin, clarithromycin and erythromycin is publicly available in LSMCA drug consumption database. As the data is presented in the international anatomic therapeutic chemical classification (ATC) system and the daily defined dose (DDD) methodology (WHO 2021), the antibiotics consumption $(\mathrm{kg})$ was recalculated from the drugs' DDD value in units of 1,000 inhabitants per day (DDD/1,000 inhabitants/day).

MMFA is presented by a Sankey diagram with loads of antibiotics given in $\mathrm{kg} / \mathrm{y}$.

\subsection{Environmental risk assessment}

The Guideline on the environmental risk assessment of medicinal products for human use, published by European Medicines Agency (EMA, 2006), is used for the research.

The research is based on theoretical and real environmental risk assessment in Lithuania. Based on the methodology of $\mathrm{C}$. Karlsson, the measured minimum effective concentration (MEC), the predicted 
environmental concentration (PEC) and the predicted no-effect concentration (PNEC) of the test substances in the environment are assessed in the research.

Klaipeda, Palanga, Kretinga and Nida municipalities were selected for the assessment. The target cities' WWTP influent/effluent concentrations were used according to MORPHEUS project output data. Under the EU Water Framework Directive, all the four wastewater treatment plants are located in the Lithuanian coastal river basin, which is attributed to the Nemunas river basin district (RBD) and covers the area of $1,077 \mathrm{~km}^{2}$, which constitutes $2.3 \%$ of the total area of the Nemunas RBD. According to the Lithuanian Department of Statistics, in 2018, the population of Lithuania amounted to approximately 2,808,900; 170,000 residents lived in Klaipeda, 13,000 - in Palanga, 18,127 - in Kretinga, 1,700 - in Nida.

$\mathrm{A}_{\text {(location, j) }}$ value is directly proportional to $\mathrm{A}_{(\text {Lithuania, j) }}$ value, which depends on $\mathrm{P}_{(\text {Lithuania) }}$. (Karlsson, 2013):

$$
A(\text { location, } \mathrm{J})=\frac{A(\text { Lithuania }, \mathrm{J})}{P(\text { Lithuania })} \times P(\text { location })
$$

1

where:

$A_{(\text {location, } j)}$ - amount of substances consumed $(j=1,2,3,4$ (Klaipeda, Palanga, Kretinga, Nida))

$\left.A_{(L i t h u a n i a, ~}\right)$ - consumption of pharmaceutical substances at the national level

$P_{(\text {Lithuania) }}$ - population

\subsubsection{Predicted environmental concentration, adapted to local conditions of antibiotics in WWTP influent and effluent wastewater}

The predicted environmental concentration $\left(\mathrm{PEC}_{\mathrm{j}}, \mathrm{k}\right)$ from a wastewater treatment plant, when $\mathrm{k}$ is influent and effluent wastewater, is calculated using the formula specified below:

$$
P E C_{j, k}=\frac{A_{\text {location }, j^{X 10^{9}}{ }_{X E_{j} X\left(1-R_{j}\right)}}}{Q_{\check{z} m^{X}} P_{\text {location }^{X 365}}}
$$

2

where:

$E_{j}$ - excretion coefficient, \%

$R_{, j}$ - wastewater treatment coefficient, \% 
$\mathrm{Q}_{\text {person }}$ - the value set by the European Medicines Agency is $200 \mathrm{l} /$ day. This is the estimated human water consumption in the survey location (EMA, 2006)

\subsection{2. $P E C$ in surface waters}

The formula specified below is used to calculate the predicted environmental concentration (PEC) of the test substances in the surface water, taking into account the dilution with water:

$$
P E C_{\text {pav. }}=\frac{A_{\text {location }, j^{X 1}}{ }^{9}{ }_{X E_{j} X\left(1-R_{j}\right)}}{Q_{\text {person } X P_{\text {location }} 365 x D}}
$$

3

where:

D - dilution factor, $\mathrm{D}=10$ (EMA, 2006)

\subsection{Environmental management system}

The environmental management system was based on the mathematical environmental system theory according to Staniškis et al. (2010). The closed interference compensation environmental management system is used in the management system. Such a system is characterised by accuracy. The main task is to find the management effect $\mathrm{U}(\mathrm{t})$ which would allow to achieve the set objectives of the management system $\mathrm{X}_{\mathrm{in}}(\mathrm{t})$. In order for the system to function, constraints on control objectives $\Delta \mathrm{X} \geq 0$ are created. The desired results will be obtained and the goal of the system $X_{\text {in }}(t)=0$ will be achieved only when the conditions do not change and when the deviation reaches zero.

$\mathrm{U}(\mathrm{t})$ - management effect which compensates for the deviation of the outputs. This parameter helps to determine the change in the concentration of the test substances that occurs in wastewater.

$\mathrm{D}(\mathrm{t})$ - interference that affects the object.

$\mathrm{X}_{\mathrm{iš}}(\mathrm{t})$ - regulated process outputs.

After the introduction of the management solution, the interference compensation device, $D(t)$ would be measured and a signal would be generated for the controller, which should theoretically reduce or eliminate the generated influence of the interference on the process parameter $\mathrm{X}_{\mathrm{iš}}(\mathrm{t})$.

\section{Results And Discussion}

\subsection{Analysis of the macrolide antibiotics substance flows in Lithuania}

\subsubsection{System definition}


Flows of the test substances - azithromycin, clarithromycin and erythromycin - are based on LSMCA data for 2015-2018 in the territory of Lithuania. The analysis examines the processes, sources of generation of pharmaceutical substances by hospitals and households, and the reasons why pollutants enter the natural environment. The research area covered three main blocks: consumption of pharmaceutical substances, disposal of pharmaceutical substances, distribution of pharmaceutical substances in the environment. The total annual consumption of the three test substances is the functional unit examined. In the substance flow analysis, processes before the distribution of substances in the environment were evaluated using numerical values.

\subsubsection{Consumption}

- Health institution sector and hospitals. In 2018, the number of hospitalized patients was estimated at 723,900 units. Based on the same statistics from the Institute of Hygiene, in 2018, the average annual number of hospital and outpatient beds was 24,051.26. Based on the data collected in the field of environmental protection, 63-69\% of all the water consumed in Lithuania were used for household needs. Given RSN 26 - 90 water consumption rates (RSN 1991), which were announced by the Ministry of Construction and Urban Development of the Republic of Lithuania and by the Environmental Protection Department of the Republic of Lithuania, the average water consumption of $240 \mathrm{l} / \mathrm{d}$ or 0,24 $\mathrm{m}^{3} / \mathrm{d}$ was specified per bed in hospitals and other institutions. An approximate calculation showed that water consumption of the outpatient sector, hospitals and other health institutions was 2,106.9 thousand m3/year. Research by Senar Aydin (2019) about the pathway of occurrence of antibiotics in hospitals and their removal from wastewater analysed 16 different city hospitals, and it was found that $13 \%$ of antibiotics ended up in wastewater (Aydin et al., 2019). This means that about $87 \%$ of the antibiotic load reach WWTPs together with wastewater. Based on this comparative article, it is assumed that wastewater from the hospital, containing antibiotics, accounts for about $9 \%$, and such a quantity reaches WWTPs.

- Public institutions and households. All the establishments that are not directly related to therapeutic activities can be attributed to the source of public institutions and households. The effluence of the pharmaceutical substances analysed may occur in places like retirement homes for the elderly, boarding houses or prisons. $17.7 \%$ of all the medicines sold are not used (Baranauskaite-Fedorova et al., 2016). According to the Department of Statistics, in 2018, the amount of unused medicines amounted to 368,593 tons. Research by Lotožienè and Patašienè (2017) on the generation and management of pharmaceutical waste in the public pharmacy showed that $26.1 \%$ of the population dispose of medicines in garbage containers, $19.1 \%$ incinerate them at home. $15.4 \%$ of the population discharge unused drugs into the sewer. As many as $21.6 \%$ of the population are unaware what to do with medical waste, $6.2 \%$ continue using them, and only $11.6 \%$ of the population bring unused medicines to the pharmacy (Lotažienè \& Patašienè, 2017). It can be concluded that about $89 \%$ of the population inappropriately dispose of expired medicines or those that are no longer usable for other reasons. It is assumed that medicines, which are not test substances, are consumed at $100 \%$ and disposed of with wastewater by extraction. To estimate the balance, it is assumed that $47.7 \%$ of the population dispose of the substances to municipal waste containers, $15.4 \%$ of the population 
discharge them into the sewer, $11.6 \%$ bring them to pharmacies, and $25.2 \%$ of the population dispose of the substances in other inappropriate ways.

- Production of pharmaceutical substances. Test substances are not produced in Lithuania. However, for a more accurate assessment it is taken into account that research performed in Lithuanian research laboratories potentially affects the mass balance. The generated part of wastewater from laboratories will not be significant or will be irrelevant to the assessment of the balance $(0.1 \%$ of all consumed pharmaceutical products per year). Such sources account for about $10 \%$ of hazardous wastewater that will be treated as hazardous, and the rest will be disposed of in a shared sewerage system (Baranauskaite-Fedorova et al., 2016).

\subsubsection{Discharge and disposal}

- Wastewater collection networks. In Lithuania, only $76.5 \%$ of the population use wastewater treatment services. After collecting data from municipalities in 2018 , it was found out that $72.9 \%$ of municipal wastewater from collection networks were generated. In 2012, $62 \%$ of wastewater were discharged to sewers, and $65 \%$ of the population used wastewater treatment services (Laurinkevičius et al., 2020). It is assumed that due to wastewater collection systems, which are not fully repaired or renovated, effluents from wastewater collection networks to surface waters will account for $1 \%$, and $1 \%$ - to the soil.

- Untreated wastewater. In Lithuania, an average of $24.2 \%$ of centrally untreated or untreated municipal wastewater is discharged into the environment every year. Due to low quality and inefficient wastewater treatment plants, $62 \%$ of municipal wastewater are not treated to the level required by legal acts, $10 \%$ - due to underdeveloped infrastructure of waste collection systems, part of wastewater is not treated due to inactive treatment plants. The amount of centrally untreated or untreated municipal wastewater, which is $24.2 \%$, is taken to calculate the flow chart. Accordingly, it is assumed, after assessing the level of non-treatment of wastewater, based on literature sources (BaranauskaiteFedorova et al., 2016), that $38 \%$ of wastewater will enter the soil and $62 \%$ - surface waters.

- Wastewater treatment plants. In 2018, data from 68 agglomerations were collected in Lithuania. 78\% of domestic, industrial and municipal wastewater, that requires treatment, were discharged from their treatment plants. The remaining $22 \%$ of wastewater, that requires treatment, are discharged from other facilities, industrial plants or small settlements (EPA, 2021). It is assumed that wastewater from patient care and other healthcare institutions is collected and treated in general wastewater treatment plants. In the flow chart, this will account for $9 \%$. As discussed in the consumption phase, $0.1 \%$ of wastewater from laboratories will enter treatment plants. In assessing the effluents of pharmaceutical residues to surface waters via WWTPs, wastewater treatment efficiency of $57 \%$ was accepted. The rate was selected, based on the research of such antibiotics already performed at WWTPs (Wang et al., 2021; Rodriguez-Mozaz et al., 2020).

- Individual wastewater treatment plants. $23 \%$ of the Lithuanian population individually treat wastewater generated by the residents themselves. The residents treat wastewater in several ways: drain wastewater into tanks and collect it there, collect wastewater in septic tanks or use treatment plants, in most cases biological wastewater treatment plants (Laurinkevičius et al., 2020). The 
analysis of water supply and wastewater treatment showed that most tanks and septic tanks are unsuitable for use because they are old, leaking and of small capacity. $80 \%$ of such wastewater enter the soil.

- Incineration and landfills. Unused medicinal products end up in landfills together with household waste. According to official waste statistics, $23 \%$ of waste are incinerated for energy purposes, $32.3 \%$ are incinerated on land. In the mass flow scheme, incineration will include household wastewater, wastewater from health institutions and laboratory waste that is treated as dangerous waste, as well as arbitrary incineration of medicines at home. $47.7 \%$ of the population dispose of $17.7 \%$ of unused pharmaceutical substances in garbage bins. Pharmaceutical substances that have started to decompose in landfills may enter surface or groundwater through the soil. In recent years, a significant improvement in landfill activities has been observed. However, a large proportion of pharmaceutical substances still enter surface waters. It is assumed that less pharmaceutical substances will enter the soil. The mass flow analysis will consider that due to improper drainage about $15 \%$ of pharmaceutical substances leach into the soil, and the rest will enter surface waters (Baranauskaite-Fedorova et al., 2016).

\subsubsection{Distribution in environment}

- Air. According to their chemical properties, the test substances are not volatile and decompose faster than manage to spread in the air. The analysed literature has revealed that there is no evidence of concentrations of antibiotic residues in the air. However, the analysis of particles in the air was performed in pig fattening farms, cattle feed grounds and pharmaceutical companies. Unfortunately, there is a lack of information about the spread of antibiotics in the air in public places.

- Sludge. Sewage sludge is a by-product of wastewater treatment. Sludge is disposed of differently around the world. In 2017, 48.3\% of sewage sludge in Lithuania were used for fertilization, $38.7 \%$ were used for composting, $0.3 \%$ were incinerated, $5.2 \%$ were disposed of otherwise (EPA, 2021). It is assumed that the test substances, that are present in the sludge, will enter the soil (Page et al., 2017).

- Soil. Concentrations of pharmaceutical substances in various soils vary widely. $38 \%$ of pharmaceutical substances will enter the soil together with untreated wastewater, $9 \%$ of pharmaceutical substances will enter the soil due to leaking and old wastewater treatment plants, $80 \%$ from tanks and septic tanks (jointly from individual treatment plants), $15 \%$ due to disposal in landfills, and $1 \%$ from wastewater collection networks.

- Surface waters and groundwater. Pharmaceutical substances will enter surface waters through the soil due to untreated and incompletely treated wastewater, low quality treatment plants and disposal of pharmaceutical substances in the landfill (EPA, 2021). Pharmaceutical substances that have penetrated into aquaculture with sediment will enter the soil by filtration, and due to water circulation will eventually enter the food chain through drinking water (Yamaguchi et al., 2015; He et al., 2016; Yamaguchi et al., 2017).

\subsubsection{Results of MMFA}


From communal households, $15.4 \%$ of pharmaceutical substances end up in sewers, $47.7 \%$ of pharmaceutical substances end up in landfills, $25 \%$ of pharmaceutical substances are incinerated arbitrarily or disposed of by other improper means, and only $11.6 \%$ of medicines brought to the pharmacy are handled correctly. Meanwhile, the majority of $17.7 \%$ of unused pharmaceutical substances is disposed of without satisfying the requirements. Raising people's environmental awareness, educating the public by promoting the fair handling of obsolete pharmaceutical substances should be the main task.

$24.3 \%$ of wastewater are untreated or not fully treated, $72 \%$ end up in treatment collection networks and $2.6 \%$ of wastewater appear in individual treatment plants. It can be argued that such a situation is due to the fact that not all residents are connected to wastewater treatment networks, the infrastructure plans are not fully implemented.

The largest amount of pharmaceutical substances goes to wastewater treatment plants. Then treated wastewater enters surface waters. However, due to the wear and age of the equipment, its efficiency decreases. The highest amount of pharmaceutical substances comes from households ( $91 \%$ ), then $9 \%$ of them come from health institutions and hospitals. This source is also important for the clear consumption of pharmaceutical substances.

All numeric MMFA results are shown in Figure 3.

\subsection{Environmental risk assessment}

\subsubsection{Study area}

Klaipeda County is one of 10 counties in Lithuania. It is the only county that borders the coastline. The coordinates: $55^{\circ} 43$ north latitude, $21^{\circ} 07$ east longitude. The county covers the area of $5,222 \mathrm{~km}^{2}$ and is the home of 320,014 residents. There are seven municipalities in Klaipeda County: Klaipeda city, Kretinga, Neringa, Palanga, Silute and Skuodas. Four municipalities were selected for the analysis of the test substances: Klaipeda, Palanga, Kretinga and Neringa (Nida). Under Water Framework Directive, all the four wastewater treatment plants are located in the Lithuanian coastal river basin district assigned to the Nemunas river basin district (RBD), and cover the area of $1,077 \mathrm{~km}^{2}$. This makes up $2.3 \%$ of the total Nemunas RBD area (EPA, 2021). In all the four wastewater treatment plants, wastewater is treated mechanically and biologically, they meet the standards and have sufficient capacity for efficient wastewater treatment. Table 1 summarizes the cleaning processes used in the treatment plants. 
Table 1

Technological treatment processes that are applied in the examined WWTPs

\begin{tabular}{|c|c|c|c|c|}
\hline WWTP area & Klaipeda & Palanga & Kretinga & Nida \\
\hline $\begin{array}{l}\text { Mechanical } \\
\text { processing } \\
\text { (lattice, sand } \\
\text { traps, settlers, } \\
\text { etc.) }\end{array}$ & \multicolumn{4}{|l|}{ applicable } \\
\hline $\begin{array}{l}\text { Primary } \\
\text { sedimentation }\end{array}$ & \multicolumn{4}{|l|}{ applicable } \\
\hline $\begin{array}{l}\text { Biological } \\
\text { processing }\end{array}$ & $\begin{array}{l}4 \text { aerotanks } \\
\text { with nitrogen } \\
\text { and } \\
\text { phosphorus } \\
\text { removal }\end{array}$ & $\begin{array}{l}2 \text { aerotanks with } \\
\text { nitrogen and } \\
\text { phosphorus removal; } \\
\text { denitrification basin; } \\
\text { anaerobic, anoxic } \\
\text { and oxy phases; } \\
\text { effluent stream entering } \\
\text { the biological } \\
\text { processing is divided } \\
\text { into denitrification and } \\
\text { dephosphation }\end{array}$ & $\begin{array}{l}2 \text { aeration tanks are } \\
\text { used for nitrogen } \\
\text { removal by } \\
\text { activated sludge } \\
\text { technology }\end{array}$ & $\begin{array}{l}\text { for the nitrogen } \\
\text { removal, } \\
\text { activated } \\
\text { sludge } \\
\text { technology is } \\
\text { used }\end{array}$ \\
\hline $\begin{array}{l}\text { Sedimentation } \\
\text { after } \\
\text { biological } \\
\text { treatment }\end{array}$ & \multicolumn{3}{|c|}{ Part of the sludge is returned back to the biological step. } & applicable \\
\hline $\begin{array}{l}\text { Chemical } \\
\text { processing }\end{array}$ & $\begin{array}{l}\text { Organic } \\
\text { carbon is } \\
\text { sometimes } \\
\text { used to } \\
\text { support } \\
\text { denitrification. }\end{array}$ & $\begin{array}{l}\text { Chemical treatment is } \\
\text { sometimes performed } \\
\text { using flocculants } \\
\text { Al203 and Brentapilus } \\
\text { VP1. }\end{array}$ & NA & NA \\
\hline Sedimentation & Sedimentation & id sludge removal & & \\
\hline
\end{tabular}

Comments:

NA - not applicable

Pursuant to the Wastewater Management Regulation prepared by the order of the Minister of Environment of the Republic of Lithuania, wastewater at these wastewater treatment plants is treated as required (Luczkiewicz et al, 2018).

\subsubsection{Trace levels of antibiotics in Klaipeda district cities wastewater}


The test substances azithromycin, clarithromycin and erythromycin were detected in the influent of Klaipeda, Kretinga, Palanga and Nida wastewater treatment plants. The highest concentrations of the test substances before treatment were detected in Kretinga in winter of 2018: azithromycin - $593.8 \mathrm{ng} / \mathrm{l}$, clarithromycin - $4113.9 \mathrm{ng} / \mathrm{l}$, erythromycin - $147.5 \mathrm{ng} / \mathrm{l}$. The lowest concentrations of the test substances before treatment were detected in Nida in summer of 2017: azithromycin - $11.9 \mathrm{ng} / \mathrm{l}$, erythromycin - 2.5 ng/l, clarithromycin - $46.7 \mathrm{ng} / \mathrm{l}$ (see Table 2).

The highest concentrations of the test substances after treatment were detected in Palanga in winter of 2018: azithromycin - $127.6 \mathrm{ng} / \mathrm{l}$, clarithromycin - 1,297.7 ng/l, erythromycin - $147.5 \mathrm{ng} / \mathrm{l}$. The lowest concentrations of the test substances after treatment were detected in Nida $-0.6 \mathrm{ng} / \mathrm{L}$ (see Table 2). In all the four cities, the highest concentrations of the test substances after treatment were of clarithromycin. Detection of pharmaceutical substances in surface water bodies in both summer and winter periods was more than $50 \%$. The total average chemical load of the test pharmaceutical substances found and tested in 2017 and 2018, which enter the four coastal wastewater treatment plants, was $47.35 \mathrm{~kg} / \mathrm{m}$. The total annual load of three pharmaceutical substances in the effluents (after treatment) was $14.49 \mathrm{~kg} / \mathrm{m}$. The highest load is in Klaipeda city WWTP, and the lowest - in Nida WWTP.

Table 2

Concentration of pharmaceutical substances (Luczkiewicz et al, 2018) and removal efficiency in the selected wastewater treatment plants

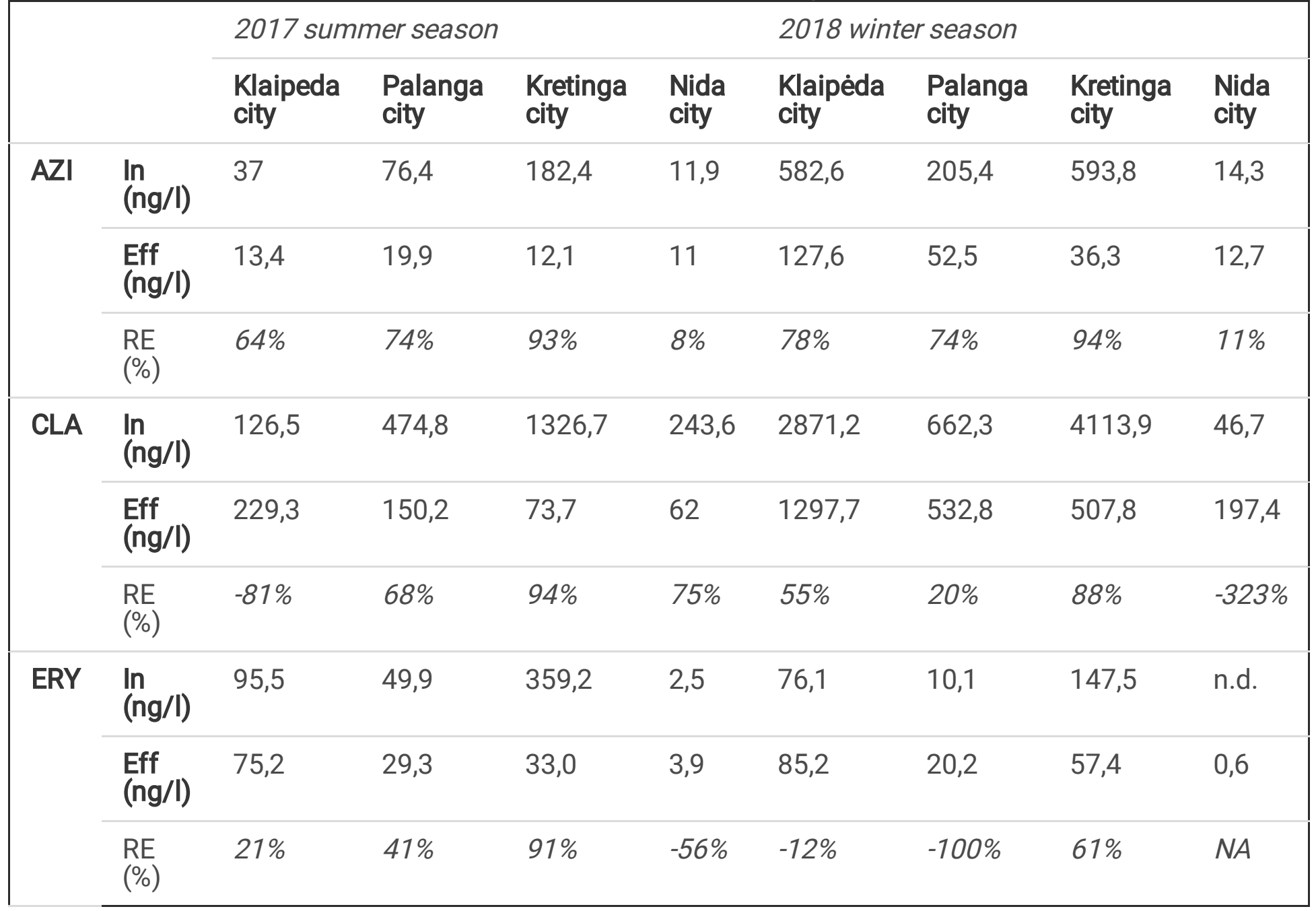


Comments:

In - influent;

Eff - effluent;

RE - removal efficiency;

n.d. - not detected;

NA - not applicable.

The study performed by Luczkiewicz et al. (2018) shows a strong influence of seasonality on the removal of AZI \& CLA antibiotic residues from wastewater. Efficiency of only about $22 \%$ was obtained in evaluating the overall efficiency of the removal of the test antibiotics during the analysed season. However, after the elimination of minus values, the average efficiency of $62 \%$ can be seen. In summer, the overall efficiency of removal of antibiotics ranges from 51 to $79 \%$, in winter - from 54 to $64 \%$. It is stated in scientific literature that between $50 \%$ and $67 \%$ of erythromycin enter the environment together with wastewater by extraction (Jessick 2010). Other antibiotics are also released into the environment - from 30-90\%, depending on their chemical composition (Aydin et al, 2019). Since macrolide antibiotics have a similar chemical composition and properties, it is assumed that about $60 \%$ of erythromycin, clarithromycin and azithromycin enter the environment through wastewater by extraction. This theoretical value will be used as the extraction coefficient $E_{j}$. The wastewater treatment coefficients Rj were selected, based on the data from the HELCOM report (HELCOM 2017).

The environmental risk assessment presented below is based on the data on the concentrations of the test substances before and after treatment in wastewater of Klaipeda, Palanga, Kretinga and Nida WWTPs.

\subsubsection{Predicted concentrations of selected antibiotics in surface waters}

The predicted concentrations of the pharmaceutical substances (azithromycin, clarithromycin, and erythromycin) in surface waters were evaluated. After assessing the dilution of the treated wastewater at the receiver, unacceptable theoretical effects of concentrations on the environment were determined. The results are presented in Table 3.

Table 3. Consumption of the test substances (kg/y.) in the study area, PEC (influents and effluents), coefficients Ej and Rj 


\begin{tabular}{|c|c|c|c|c|c|c|}
\hline $\begin{array}{l}\text { Target } \\
\text { pharmaceutical } \\
\text { substance }\end{array}$ & $\begin{array}{l}\text { Consumption in } \\
\text { Lithuania, } \\
\mathrm{kg} / \mathrm{m} \text {. }\end{array}$ & $\begin{array}{l}\text { Consumption in Klaipeda, } \\
\text { Palanga, Kretinga and } \\
\text { Nida, } \mathrm{kg} / \mathrm{m} \text {. }\end{array}$ & $\begin{array}{l}{ }^{*} \text { PECj, } \\
\text { in } \\
\text { influent } \\
\mu \mathrm{g} / \mathrm{l}\end{array}$ & $\begin{array}{l}{ }^{*} \text { PECj, } \\
\text { in } \\
\text { effluent } \\
\mu \mathrm{g} / \mathrm{l}\end{array}$ & $\begin{array}{l}E_{j,} \\
\%\end{array}$ & $\begin{array}{l}{ }^{* *} \mathrm{R}_{\mathrm{j}}, \\
\%\end{array}$ \\
\hline AZI & 0,31 & 0,021 & 0,91 & 0,24 & \multirow[t]{3}{*}{60} & 73 \\
\hline CLA & 2,18 & 0,147 & 6,38 & 4,21 & & 34 \\
\hline ERY & 0,11 & 0,007 & 0,32 & 0,037 & & 91 \\
\hline
\end{tabular}

Comments:

* reference to HELCOM, 2017;

** reference to Luczkiewicz et al. 2017-2019 MORPHEUS project.

Table 4. The PEC, PNEC values of the test substances that have been analysed and the results of PEC/PNEC (Loos et al., 2018)

\begin{tabular}{|llll|}
\hline Target pharmaceutical substance & PEC $_{\text {pav }}$ & PNEC & PEC/PNEC \\
\hline AZI & $0,024 \mu / \mathrm{l}$ & $0,019 \mu \mathrm{g} / \mathrm{l}$ & $1,26 \mu \mathrm{g} / \mathrm{I}$ \\
\hline CLA & $0,42 \mu \mathrm{g} / \mathrm{l}$ & $0,12 \mu \mathrm{g} / \mathrm{l}$ & $3,5 \mu \mathrm{g} / \mathrm{l}$ \\
\hline ERY & $0,0037 \mu \mathrm{g} / \mathrm{l}$ & $0,2 \mu \mathrm{g} / \mathrm{l}$ & $0,0185 \mu \mathrm{g} / \mathrm{l}$ \\
\hline
\end{tabular}

Concentration of clarithromycin in the effluents in Klaipeda is MEC/PNEC $>10$. There is a high risk that the effluents from WWTP pose threat to the natural environment.

Table 5 presents comparison of measured environmental concentrations MEC of the test substances and of predicted environmental concentrations PEC of the test substances. PNEC was evaluated according to the information in Table 4. 
Table 5

Comparison of measured and predicted concentration of the test substances in wastewater

\begin{tabular}{|c|c|c|c|c|}
\hline \multirow[t]{2}{*}{ Target pharmaceutical substance } & \multicolumn{4}{|c|}{ PEC (influent/effluent), $\mu \mathrm{g} / \mathrm{l}$} \\
\hline & Klaipeda & Palanga & Kretinga & Nida \\
\hline AZI & $0,92 / 0,25$ & $0,91 / 0,24$ & $0,91 / 0,24$ & $0,91 / 0,24$ \\
\hline CLA & $6,38 / 4,21$ & $6,38 / 4,21$ & $6,38 / 4,21$ & $6,38 / 4,21$ \\
\hline \multirow[t]{3}{*}{ ERY } & $0,32 / 0,03$ & $0,32 / 0,03$ & $0,32 / 0,03$ & $0,32 / 0,03$ \\
\hline & \multicolumn{4}{|c|}{ MEC (influent/effluent), $\mu \mathrm{g} / \mathrm{I}$} \\
\hline & Klaipeda & Palanga & Kretinga & Nida \\
\hline AZI & $0,583 / 0,128$ & $0,205 / 0,053$ & $0,594 / 0,036$ & $0,014 / 0,013$ \\
\hline CLA & $2,871 / 1,298$ & $0,662 / 0,533$ & $4,114 / 0,508$ & $0,047 / 0,197$ \\
\hline \multirow[t]{3}{*}{ ERY } & $0,076 / 0,085$ & $0,010 / 0,020$ & $0,148 / 0,057$ & $\mathrm{nd} / 0,0006$ \\
\hline & \multicolumn{4}{|c|}{ MEC/PNEC (influent/ effluent), $\mu \mathrm{g} / \mathrm{l}$} \\
\hline & Klaipeda & Palanga & Kretinga & Nida \\
\hline AZI & $30 / 6,71$ & $10,8 / 2,76$ & $31,3 / 1,91$ & $0,75 / 0,67$ \\
\hline CLA & $23,93 / 10,81$ & $5.51 / 4,44$ & $34,3 / 4,2$ & $0,39 / 1,65$ \\
\hline \multirow[t]{3}{*}{ ERY } & $0,38 / 0,43$ & $0,05 / 0,1$ & $0,74 / 0,29$ & $\mathrm{nd} / 0,003$ \\
\hline & \multicolumn{4}{|c|}{ PEC/MEC (influent/effluent), ng/l } \\
\hline & Klaipeda & Palanga & Kretinga & Nida \\
\hline AZI & $1,58 / 1,96$ & $4,43 / 4,57$ & $1,5 / 6,6$ & $65 / 20$ \\
\hline CLA & $2,2 / 3,24$ & $9,63 / 7,9$ & $1,56 / 8,3$ & $137 / 21$ \\
\hline ERY & $4,2 / 0,35$ & $32 / 1,49$ & $2,2 / 0,5$ & $\mathrm{nd} / 50$ \\
\hline
\end{tabular}

Reliability of the risk assessment of measured and predicted concentrations of the test substances is assessed according to the Coetsier set of criteria. The calculated PECs may be acceptable $(0.2<\mathrm{PEC} / \mathrm{MEC}$ $<1)$, acceptable with minor overestimation $(1<\mathrm{PEC} / \mathrm{MEC}<4)$, significantly overestimated $(4<\mathrm{PEC} / \mathrm{MEC}<8)$ or severely overestimated (PEC/MEC> 8) (Mustafa, 2011).

Predicted concentrations of the test substances can depend on many factors. Therefore, this methodology may distort the results presented and their true concentrations. This may be due to an unexpected increase in population (during the summer season). For this reason, significantly higher concentrations are seen in areas with smaller population. This can also be due to other factors, such as standards of living, morbidity, age. After a good evaluation of deviations in the results, this methodology could be used when it is not possible to measure concentrations of pharmaceutical substances or other pollutants. 


\subsection{Application of the environmental management system theory to manage the concentrations of pharmaceutical substances - antibiotics in wastewater}

The Environmental management system is aimed at reducing pollution of pharmaceutical substances azithromycin, clarithromycin and erythromycin in the aquatic environment. Theoretically, the main task of the management system is to find such a control effect $\mathrm{U}(\mathrm{t})$ and factors appropriate for it which would allow to set objectives for the management system $\left(X_{\text {in }}(t)\right)$ that are to be achieved (Staniškis et al, 2010). The main task of the management system is to reduce the negative impact on the environment by such pollution prevention measures that would be the most cost-effective.

Wastewater containing azithromycin, clarithromycin and erythromycin constitutes the object of the research. The concentration of the test substances $(\mathrm{ng} / \mathrm{l})$ and the quantity of the substances consumed in Lithuania per year (kg per year) are the variables of the state of the system. Concentration of wastewater containing antibiotics $(\mathrm{ng} / \mathrm{l})$ is the object managed. The objective of the system: $X_{i n}(t)=0$. The strategy on how to gradually reduce pharmaceutical contamination up to complete control and leak termination is developed. To achieve results, gradual reduction of the system objective $X_{i \check{s}}(t)$ is proposed:

up to $2025 \mathrm{X}_{\text {in }} \rightarrow 1 / 4 \mathrm{X}_{\text {iš }}$

up to $2030 \mathrm{X}_{\text {in }} \rightarrow 1 / 2 \mathrm{X}_{\text {iš }}$

up to $2035 \mathrm{X}_{\text {in }} \rightarrow 0 \mathrm{X}_{\text {iš }}$

The management system is presented in Figure 4.

In order to achieve the objective, it is recommended to take into account economic and environmental aspects. The following basic system controls are proposed:

1. Integration of efficient, more modern management processes in water and wastewater treatment plants of Lithuanian cities.

2. Legal changes in connection with removal of pharmaceutical substances from wastewater.

3. More active monitoring of the flows of pharmaceutical substances.

Mechanical and biological treatment processes, and mainly activated sludge technology are used in Lithuanian wastewater treatment plants for wastewater treatment. In Lithuania, wastewater is treated quite well and meets regulatory requirements. However, there is very little information and very little research has been done as to how to remove pharmaceutical substances from wastewater and achieve a reduction in their pollution. The fourth stage treatment technology is suggested to be implemented, to supplement the existing system with ozonation or activated carbon technologies (Luczkiewicz et al., 2018, Baresel et al., 2015). After modernization of wastewater treatment plants, theoretically the direct load of pollutants should decrease by $60-70 \%$ (Baresel et al., 2015). In addition, new advanced wastewater treatment technologies, such as electrochemical treatment, use of enzymes, fenton, fungi, coagulation or flocculation, are being developed. Other advanced oxidation technologies can also be applied. For better cleaning efficiency, connecting ozone and filter systems has been suggested as well. 
Following the MMFA, it is observed that the highest consumption of pharmaceutical substances is in households, where it is quite difficult to control wastewater. Separation of domestic wastewater flows from other generated flows is a possible solution for broader analysis and monitoring in the environment and for the assessment in which flows the highest pollutant loads occur after domestic wastewater. After separating the flows, it would be possible to monitor other flows more actively and find new solutions to control them. For example, after separating flows of hospitals and the outpatient sector, it would be possible to treat wastewater before handing it over to urban wastewater treatment plants (WWTP). Besides, after assessing the efficiency of wastewater facilities, it would be possible to make more efficient and easyto-implement solutions for further wastewater treatment.

There is still no legal basis in Lithuania for the removal of pharmaceutical substances from wastewater. More detailed data on the concentrations of pharmaceutical substances in surface water in Lithuania were obtained from the implemented MORPHEUS project.

\section{Conclusions}

Scientific literature analysis of macrolide antibiotics distribution in the environment gave a strong baseline for the material flow analysis. Following the findings of the performed analysis regarding pharmaceuticals waste management in Lithuania and Europe, it was determined that the major part of $17.7 \%$ of unused pharmaceutical substances is disposed of in non-compliance with the requirements. $15.4 \%$ of pharmaceutical substances from communal households end up in sewers, $47.7 \%$ of pharmaceutical substances end up in landfills, $25 \%$ of pharmaceutical substances are incinerated arbitrarily or disposed of by other improper means, and only $11.6 \%$ of medicines brought to the pharmacy are handled correctly. $24.3 \%$ of wastewater are untreated or not fully treated, $72 \%$ end up in treatment collection networks and $2.6 \%$ of wastewater appear in individual treatment plants. The material flow analysis showed that $91 \%$ pharmaceutical substances come from households and most of them end up in wastewater treatment plants.

Regarding the material flow analysis, two most significant factors were identified, which should be controlled in order to prevent surface waters from pollution by emerging substances or reduce the contamination as much as it is possible:

- households as the main source of pollution by the pharmaceutical residues. Such substances are disseminated naturally to the environment via sewage collectors by the pharmaceutical consumers;

- treatment plants as the main source of pollution release into the environment that requires a high concern of the current status WWT facilities and capability of wastewater treatment, moreover feasibility of advanced waste water treatment technologies.

The risk assessment of the test substances revealed that the ratio between the predicted no-effect concentration of the pharmaceutical substances azithromycin and clarithromycin in the environment is greater than 1 (PEC/PNEC> 1). This indicates that these substances may pose significant risks. Meanwhile, 
the ratio between the predicted concentration in the environment and the predicted no-effect concentration in the environment of erythromycin is below $1(\mathrm{PEC} / \mathrm{PNEC}<1)$, and this indicates that the risk to the environment is acceptable. The concentration of clarithromycin in the effluents in Klaipeda, that is, the ratio between the measured concentration and the predicted no-effect concentration in the environment of clarithromycin is greater than 10 (MEC/PNEC>10), particularly high risk is foreseen, the effluents from WWTP pose threat to the natural environment.

Based on the research carried out, the environmental management system of the test pharmaceutical substances was proposed for reducing pollution. A management system was set up providing recommendations related to modernization of technologies, updating of analyses and research, improvement of legal acts and financing of projects, development of new medicines and raising consumer awareness. After the application of preventive and technological management measures, the expected efficiency should be up to $50 \%$.

There are many signs that new legal requirements for the management of wastewater contaminated with pharmaceutical substances will soon be developed in Lithuania, as there are numerous initiatives regarding micropollutants and pharmaceuticals in water cycles and wastes containing medicines. Particular attention should be paid to the qualitative parameters of:

- pharmaceuticals usage and consumption in general;

- prescribing minimized dose of medications to patients only when necessary;

- advanced and high-quality pharmaceutical residues treatment from healthcare facilities and WWTP.

Consumers should be better educated not only about the benefits of antibiotics, but also about the harm they cause to the environment and to human.

This type of research is particularly important in the development of River Basin Management Plans and might contribute to the development of water management policies at local, regional and national levels.

\section{Abbreviations}

AA-EQS - Annual Average Environmental Quality Standard

ATC - Anatomic Therapeutic Chemical

AZI - Azithromycin

BOD - Biochemical Oxygen Demand

CLA - Clarithromycin

DDD - Defined Daily Dose 
EPA - Environmental Protection Agency

ERY - Erythromycin

EMA - European Medicine Agency

LLE - Liquid-Liquid Extraction

LSMCA - Lithuanian State Medicines Control Agency

LC/MS - Liquid Chromatography/Mass Spectrometry

MEC - Measured Environmental Concentration

MMFA - Mathematical Material Flow Analysis

NOEC - No-Observed-Effect Concentration

PE - People Equivalent

PEC - Predicted Environmental Concentration

PhS - Pharmaceutical Substances

PNEC - Predicted No-Effect Environmental Concentration

RL - Republic of Lithuania

RBD - River Basin District

SFA - Substance Flow Analysis

WWT - Wastewater Treatment

WWTP - Wastewater Treatment Plants

WHO - World Health Organization

\section{Statements And Declarations}

\section{Acknowledgement}

This research was developed in the framework of the INTERREG EUROPE programme project "Improving the European Rivers Water Quality through Smart Water Management Policies - BIGDATA4RIVERS" funded by the EU's European Regional Development fund through the INTERREG EUROPE, 2014-2020. 
All co-authors (Inga Baranauskaite-Fedorova, Reda Beigaite, Jolanta Dvarioniene) of this paper consent participating in the preparation of this manuscript.

\section{Consent to Publish}

All co-authors (Inga Baranauskaite-Fedorova, Reda Beigaite, Jolanta Dvarioniene) of this paper consent to publish data of this manuscript.

\section{Ethical approval}

For this paper not applicable.

\section{Funding}

The authors declare that no funds, grants, or other support were received during the preparation of this manuscript.

\section{Competing interests}

The authors have no relevant financial or non-financial interests to disclose.

\section{Author contribution}

All authors contributed to the study conception and design. Material preparation, data collection and analysis were performed Inga Baranauskaite-Fedorova, Reda Beigaite, Jolanta Dvarioniene. The first draft of the manuscript was performed by Inga Baranauskaite-Fedorova and all authors commented on previous versions of the manuscript. All authors read and approved the final manuscript.

\section{Availability of data and materials}

All co-authors (Inga Baranauskaite-Fedorova, Reda Beigaite, Jolanta Dvarioniene) of this paper consent that all data and materials claim and comply with the field standards.

\section{Data availability}

All co-authors (Inga Baranauskaite-Fedorova, Reda Beigaite, Jolanta Dvarioniene) of this paper consent that all data and materials claim and comply with the field standards.

\section{References}

1. Aydin S, Aydin ME, Ulvi A, Kilic H (2019) Antibiotics in hospital effluents: occurrence, contribution to urban wastewater, removal in a wastewater treatment plant, and environmental risk assessment. Environ Sci Pollut Res Int 26(1):544-558. doi: 10.1007/s11356-018-3563-0;

2. Bader HP, Scheidegger R (2017) MMFA (Mathematical Material Flow Analysis) Framework. Swiss Federal Institute of Aquatic Science and Technology (Eawag), p 1-56, 
https://www.dora.lib4ri.ch/eawag/islandora/object/eawag\%3A22071/datastream/PDF/Bader-2017MMFA_\%28mathematical_material_flow_analysis\%29_framework-\%28published_version\%29.pdf

3. Baranauskaitè I, Dvarionienè J (2014a) Presence and Detection of Pharmaceutical Substances (Diclofenac, 17-beta-estradiol, 17-alfa-etilinestradiol) in the Environment. Future Challenges for Lithuania. Environ Res Eng Manage 68(2):27-43. https://doi.org/10.5755/j01.erem.68.2.7378;

4. Baranauskaitè I, Dvarionienè J (2014b) Occurrence and Removal Possibilities of Diclofenac, 17-betaEstradiol and 17-alfa-Ethinylestradiol in Wastewater of Lithuanian Urban Areas. 12th international conference Littoral 2014, Abstract book, p 101

5. Baranauskaite-Fedorova I, Dvarioniene J, Nikiforov VA (2016) Management of pharmaceutical substances in the environment: Lithuanian case study. Water Sci Technol 74(6):1255-1265. https://doi.org/10.2166/wst.2016.289;

6. Baresel C, Cousins AP, Hörsing M, Ek M, Ejhed H, Allard AS, Magnér J, Westling K, Wahlberg C, Fortkamp U, Söhr S (2015) Pharmaceutical Residues and Other Emerging Substances in the Effluent of Sewage Treatment Plants - Review on Concentrations, Quantification, Behaviour, and Removal Options. Report 2226, IVL Swedish Environmental Research Institute, Stockholm, Sweden, https://sjostad.ivl.se/download/18.15a855cb14c38029e641382/1430315031950/B2226.pdf

7. Ben Y, Fu C, Hu M, Liu L, Wong MH, Zheng C (2019) Human health risk assessment of antibiotic resistance associated with antibiotic residues in the environment: A review. Environ Res 169:483-493. doi: 10.1016/j.envres.2018.11.040;

8. Bengtsson-Palme J, Erik Kristiansson E, Larsson DGJ (2018) Environmental factors influencing the development and spread of antibiotic resistance. FEMS Microbiol Rev 42:68-80. https://doi.org/10.1093/femsre/fux053;

9. Chen Y, Cui K, Huang Q, Guo Z, Huang Y, Yu K, He Y (2020) Comprehensive insights into the occurrence, distribution, risk assessment and indicator screening of antibiotics in a large drinking reservoir system. Sci Total Environ 716:137060. doi: 10.1016/j.scitotenv.2020.137060;

10. COM (2020) Communication from the Commission to the European Parliament, the Council, the European Economic and Social Committee and the Committee of The Regions Pharmaceutical Strategy For Europe COM/2020/761 Final, https://eur-lex.europa.eu/legal-content/EN/TXT/? uri=CELEX\%3A52020DC0761

11. Environmental Protection Agency (2021) Ministry on Environment of the Republic of Lithuania, https://gamta.lt/cms/index

12. European Medicines Agency (2006) Guidance for RA, no. June, p 1-12, https://www.ema.europa.eu/en/documents/scientific-guideline/guideline-environmental-riskassessment-medicinal-products-human-use-first-version_en.pdf

13. He X, Deng M, Wang Q, Yang Y, Nie X (2016) Residues and health risk assessment of quinolones and sulfonamides in cultured fish from Pearl River Delta, China. Aquaculture 458:38-46. doi: 10.1016/j.aquaculture.2016.02.006;

14. HELCOM (2017) Pharmaceuticals in the aquatic environment of the Baltic Sea region A status report International Initiative on Water Quality-IIWQ, no. 149, 
https://helcom.fi/media/publications/BSEP149.pdf

15. HELCOM (2018) Baltic Marine Environment Protection Commission. Implementation of the Baltic Sea Action Plan 2018, p 1-91, https://helcom.fi/wp-content/uploads/2019/06/Implementation-of-theBSAP-2018.pdf

16. Hu Y, Yan X, Shen Y, Di M, Wang (2018) Antibiotics in surface water and sediments from Hanjiang River, Central China: Occurrence, behavior and risk assessment. Ecotoxicol Environ Saf 157:150-158. doi: 10.1016/j.ecoenv.2018.03.083;

17. Yamaguchi T, Okihashi M, Harada K, Konishi Y (2017) Detection of antibiotics in chicken eggs obtained from supermarkets in Ho Chi Minh City, Vietnam. J Environ Sci Health B 52(6):430-433. doi: 10.1080/03601234.2017.1293457;

18. Yamaguchi T, Okihashi M, Harada K, Konishi Y, Uchida K, Do MHN, Bui HDT, Nguyen TD, Nguyen PD, Chau VV, Dao KTV, Nguyen HTN, Kajimura K, Kumeda Y, Bui CT, Vien MQ, Le NH, Hirata K, Yamamoto Y (2015) Antibiotic residue monitoring results for pork, chicken, and beef samples in Vietnam in 20122013. J Agric Food Chem 2015 Jun 3(21):5141-5145. doi: 10.1021/jf505254y;

19. Jessick AM (2010) Detection, fate, and bioavailability of erythromycin in environmental matrices. Graduate Theses and Dissertations, lowa State University, p 1-99

20. Karlsson C (2013) Risk assessment of compounds that could impair the aquatic environment. Ecotoxicol no 131:1-56

21. Latožienè R, Patašienė $D$ (2017) Farmacinių atliekų susidarymas ir tvarkymas visuomenès vaistinejje // The accumulation and management of pharmaceutical waste in the community pharmacy. Master degree thesis, Vilnius University, p 1-67

22. Laurinkevičius A, Pacevičiūtè T, Pupeikytė-Usačiova R, Aliulis A, Musteikis T, Blinkevičiūtè D, Perle B (2020) State control audit report - Vandens Tiekimas ir Nuotekų Tvarkymas/ Water supply and sewage treatment. 2020 November 19, No. VAE-12

23. Loos R, Marinov D, Sanseverino I, Napierska D, Lettieri T (2018) Review of the 1st Watch List under the Water Framework Directive and recommendations for the 2nd Watch List. no. April;

24. Luczkiewicz A, Fudala-Ksiazek S, Jankowska K, Szopinska M (2018) Overview of advanced technologies in wastewater treatment for removal of pharmaceuticals and other micropollutants. Project MORPHEUS 2017 - 2019. Gdansk University of Technology, Poland;

25. Mustafa AA (2011) Environmental Risk of Pharmaceuticals in Waters: Investigation on their Occurrence and Removal in Conventional Treatment Plants. Disertation, University of Ferrara, Ferrara, Italy, pp 1-304

26. Page GL, Gunnarsson L, Snape J, Tyler CR (2017) Integrating human and environmental health in antibiotic risk assessment: A critical analysis of protection goals, species sensitivity and antimicrobial resistance. Environ Int 2017 Dec 109:155-169. doi: 10.1016/j.envint.2017.09.013;

27. Rodriguez-Mozaz S, Vaz-Moreira I, Varela S, Giustina D, Llorca M, Barceló D, Schubert S, Berendonk TU, Michael-Kordatou I, Fatta-Kassinos D, Luis Martinez J, Elpers C, Henriques I, Jaeger T, Schwartz T, Paulshus E, O'Sullivan K, Pärnänen KMM, Virta M, Manaia CM (2020) Antibiotic residues in final 
effluents of European wastewater treatment plants and their impact on the aquatic environment. Environ Int 140:10573. https://doi.org/10.1016/j.envint.2020.105733;

28. RSN (1991) LR Statybos ir Urbanistikos ministerija ir LR Aplinkos Apsaugos departamentas, "Vandens vartojimo normos RSN 26-90" nr. 79, 1991 // RSN 1991. Ministry of Construction and Urban Development of the Republic of Lithuania and Department of Environmental Protection of the Republic of Lithuania, "Water consumption norms RSN 26-90" no. 79, 1991

29. Staniškis J, Stasiškiene Ž, Kliopova I, Varžinskas V (2010) Darniosios inovacijos Lietuvos pramone je: kūrimas ir diegimas // Sustainable Innovations in Lithuania Industry: Development and Implementation. Technologija, Kaunas;

30. Wang K, Zhuang T, Su Z, Chi M, Wang H (2021) Antibiotic residues in wastewaters from sewage treatment plants and pharmaceutical industries: Occurrence, removal and environmental impacts. Sci Total Environ 788:147811. https://doi.org/10.1016/j.scitotenv.2021.147811;

31. WHO Collaborating Centre for Drug Statistics Methodology (2021) ATC classification index with DDDs, Oslo, Norway. https://www.whocc.no/atc_ddd_index/

\section{Figures}

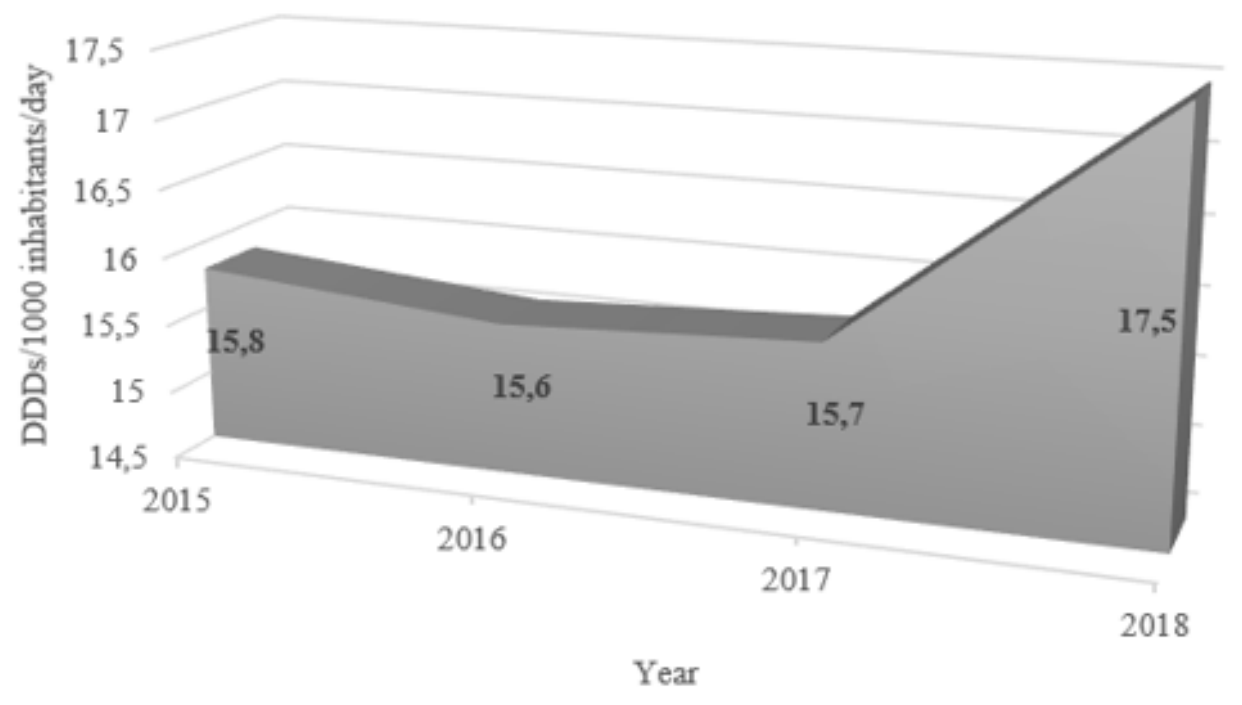

Figure 1

Consumption of antibiotics in Lithuania in 2015-2018 


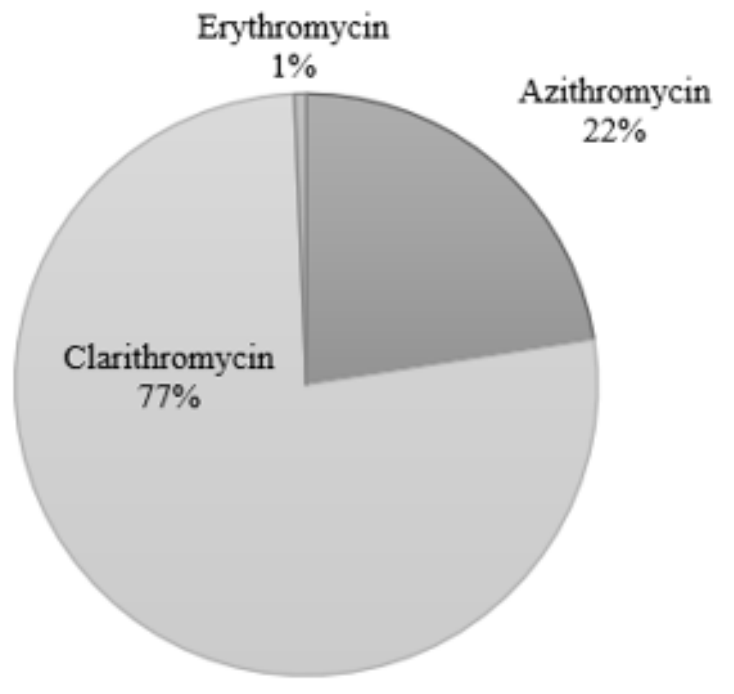

\section{Figure 2}

Average consumption of the test substances in Lithuania in 2015-2018

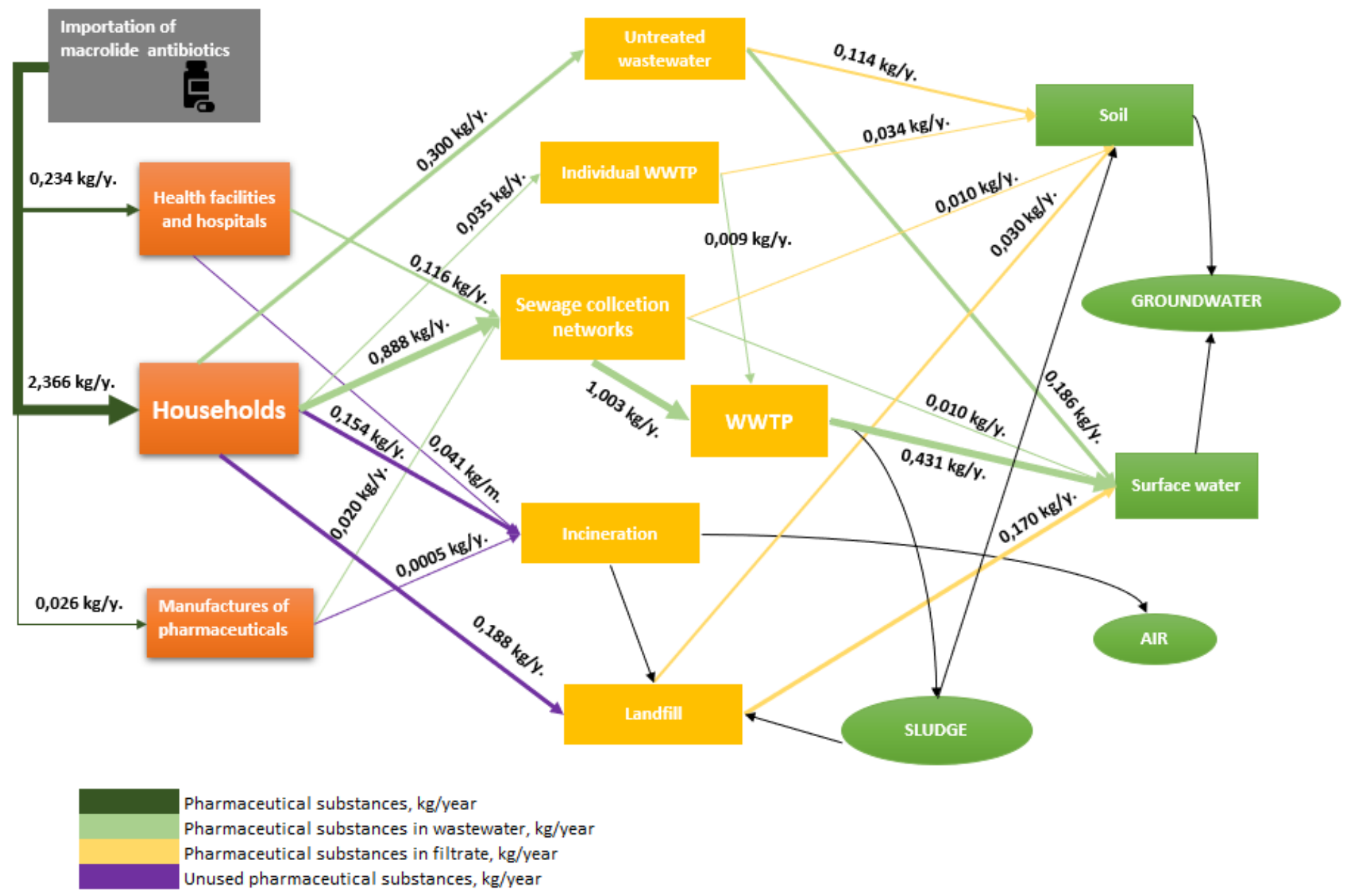

\section{Figure 3}

Macrolide antibiotics (erythromycin, clarithromycin and azithromycin) flows in Lithuania in 2018 


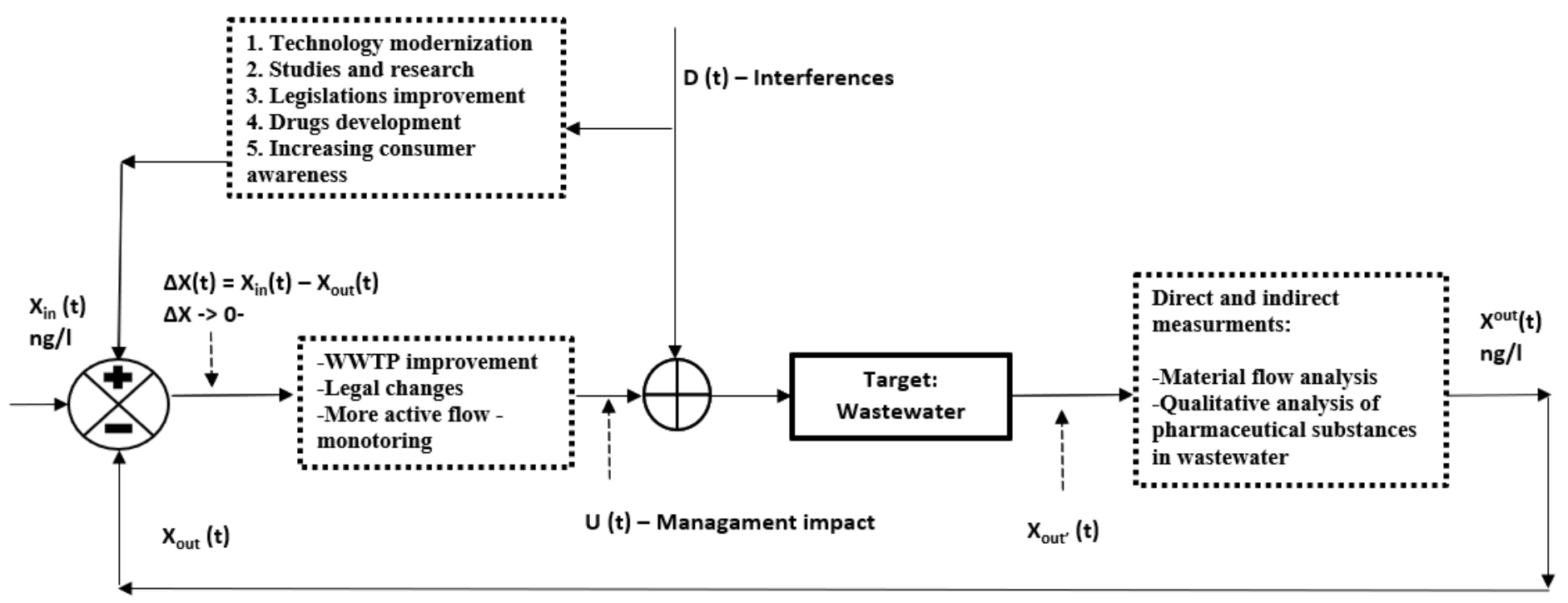

Figure 4

Environmental management system for waste water containing pharmaceutical substances azithromycin, clarithromycin and erythromycin 